Sports Science

\title{
Female military pentathlon athletes and scientific research - a mini- review
}

\author{
Míriam Raquel Meira Mainenti ${ }^{1}$ (D), Bianca Miarka ${ }^{2}$ (D), Marcos Vinícius Marques Loyola ${ }^{1,2,3}$ (D), \\ Lucas Vieira Coelho dos Santos ${ }^{1,3}$, Danielli Braga de Mello ${ }^{1}$ \\ ${ }^{1}$ Escola de Educação Física do Exército, Rio de Janeiro, RJ, Brazil; ${ }^{2}$ Universidade Federal do \\ Rio de Janeiro, Escola de Educação Física e Desportos, Rio de Janeiro, RJ, Brazil; ${ }^{3}$ Comissão de \\ Desportos do Exército, Rio de Janeiro, RJ, Brazil.
}

Associate Editor: Angelina Zanesco (D), ${ }^{1}$ Universidade Metropolitana de Santos, Faculdade de Medicina, Santos, SP, Brazil; 'Universidade Estadual Paulista "Júlio de Mesquita Filho", Departamento de Educação Física, Instituto de Biociências, Rio Claro, SP, Brazil. E-mail: angelina.zanesco@unesp.br.

\begin{abstract}
Aim: to compile existing information in the scientific literature on female military pentathlon athletes. Methods: searches were performed on Pubmed/Medline, Scielo, and Scholar Google databases with specific strings in English and Portuguese. Results: military pentathlon is a discipline that comprises five events, namely: rifle shooting, obstacle run, obstacle swimming, throwing, and cross country running. Our search initially identified 275 records, which were reduced to the final list of 14 after the eligibility criteria analysis was performed in two phases: title + abstract reading and full-text reading. The first record was published in 2007 (recent field of study) and most studies were cross-sectional ones (scarcity of experimental studies), investigating outcomes like psychological, anthropometric, biochemical, biomechanics, cardiopulmonary, nutritional, skin temperature, performance, and prevalence of injury. The female military pentathlon athletes present low values of body fat, energy intake, and high weekly training volume, so professionals must be aware to prevent relative energy deficiency in sports (RED-S) syndrome. The obstacle run was the most investigated event, with lower blood lactate and skin temperature for women athletes. It was also observed that anthropometric, muscle power, and cardiopulmonary variables are well correlated with athletic performance and in some studies, these correlations were stronger for female athletes. Conclusion: scientific research with female military pentathlon athletes is still incipient, especially for experimental design researches, which are highly encouraged in future studies.
\end{abstract}

Keywords: athletic performance, sports, military personnel, sex characteristics, sports medicine.

\section{Introduction}

Over the past three decades, there has been a steady increase in women's involvement in sports events in Brazil and around the world. Data from the International Olympic Committeee ${ }^{1}$ showed an increase in approximately $13 \%$ in women participation from Atlanta (1996) - 36\% to Tokyo (2020/2021) - 48.8\%. A similar increase is observed in World Military Games (WMG), from 12\% of female participation in Rome (1st WMG, 1995) to $33 \%$ in Wuhan (last WMG, 2019) ${ }^{2}$, mainly caused by a greater entry of women into military career ${ }^{3,4}$.

In the Brazilian Army (BA), women recently started to entry into combat career paths ${ }^{5}$. The first combat female military were graduated in 2018 by Escola de Sargentos das Armas and in 2021 by Academia Militar das Agulhas Negras. These women joined others who work in other areas of the BA, such as health and administrative, as well as military personnel from the Air Force and the Navy, which previously included women in the Air Force Academy and Naval School ${ }^{4}$.

One BA recently published guideline stated that female participation should be encouraged in all military sports championships, including military pentathlon ones ${ }^{6}$. This scenario improved female participation in different disciplines practiced by athletes from the Armed Forces. Among them, the military pentathlon, consisting of five events closely correlated to military training or real operations. It is composed of shooting with a standard rifle, obstacle run, obstacle swimming, throwing, and cross country ${ }^{7}$. Because of this specific characteristic, it is a high valued discipline in the military field ${ }^{8}$.

Despite the existence of men, military pentathlon competitions since the mid-twentieth century ${ }^{9}$, only at the end of the century (1991) women were included in the annual world championships, which brings an essential 
paradigm for investigations: what would be the differences between female and male athletes in the sport and how would this impact the specifics of performance training? Studies on this topic would help both in sports performance, as well as in military operations since the practice of military pentathlon is multifactorial and contextual to what happens in military environments.

The rise in people practicing military pentathlon, especially women who recently entered BA, highlighted the importance of research development in this field of study. Researches that could support professionals from the team technical committees adding information to assist them in the selection of athletes and the choice of variables that could identify the effectiveness of applied interventions. Researches that could help them select the better stimuli to be applied at each phase of the training, ensuring better increases in athletic performance. The organization and compilation of this knowledge in a single document (this mini-review), focusing on female military athletes (a growing public) can be useful for professionals working with this group, as well as for other women who practice multi-event sports. Thus, this review objective was to compile existing information in the scientific literature on female military pentathlon athletes.

\section{Methods}

Searches were performed on Pubmed/Medline, Scielo, and Scholar Google databases to select articles published before October 20, 2021, including all types of studies, available both as abstract or full-text articles, in English and Portuguese. Studies in which female outcomes could not be clearly discriminated from male ones; studies with only male athletes; studies of other disciplines (as modern pentathlon), studies in which military pentathlon athletes could not be clearly discriminated from other athletes and animal models were excluded from the present review. The strings for each database are presented in Table 1.

Additional records through other sources were included after identifying interesting references while reading the selected papers and also by the knowledge of the

Table 1 - String for each database in English and Portuguese.

\begin{tabular}{|c|c|}
\hline Databases & Strings \\
\hline Pubmed/Medline & $\begin{array}{c}\text { "military pentathlon" AND (women OR woman OR } \\
\text { female OR girl) }\end{array}$ \\
\hline \multirow[t]{2}{*}{ Scielo } & $\begin{array}{c}\text { (military pentathlon) AND (women OR woman OR } \\
\text { female OR girl) }\end{array}$ \\
\hline & $\begin{array}{l}\text { (pentatlo militar) AND (mulher OR feminino OR } \\
\text { feminina OR menina OR garota) }\end{array}$ \\
\hline \multirow[t]{2}{*}{ Google Scholar } & $\begin{array}{l}\text { women OR woman OR female OR girl "military } \\
\text { pentathlon" }\end{array}$ \\
\hline & $\begin{array}{l}\text { mulher OR feminino OR feminina OR menina OR } \\
\text { garota "pentatlo militar" }\end{array}$ \\
\hline
\end{tabular}

authors of this mini-review since we are closely involved with female military pentathlon Brazilian team training.

\section{Result and Discussion}

\section{The female military pentathlon}

Before presenting the results of the search itself, we described some military pentathlon characteristics and data, so that all readers would be able to better understand the main findings of this review.

The military pentathlon's regulations are established by the International Military Sports Council (CISM) and this discipline comprises five events, namely: rifle shooting, obstacle run, obstacle swimming, throwing, and cross country running ${ }^{7}$. All performances are conversed into points of pentathlon (PP), using specific table data as determined by CISM $^{7}$.

The shooting with a standard rifle is a high technique event, demanding high levels of concentration, psychological and body balance ${ }^{10}$. In this event, athletes perform a total of 20 shots lying on the shooting mat (Figure 1A) and the competition consists of two shooting types: slow fire and rapid-fire. There are no differences between the execution of the male and female shooting competition in the military pentathlon, and the results presented by both sexes in competitions are very similar. The men's world record is 200 points, while the women's is 199 points. The Brazilian record among women in the shooting competition is 196 points, obtained by soldier Naiana, from the Military Fire Department of the State of Rio de Janeiro.

The obstacle run event, consisting of a route of $500 \mathrm{~m}$ (duration between 2'09" and 2'50" for high-performance athletes) is characterized by the predominance of the lactic anaerobic system combined with high levels of physical fitness and skills for the efficient transposition of each obstacle ${ }^{11}$. Some of the body movements involved are: jumps of varying heights, falls (reaching the maximum height of five meters for males and two meters for female athletes), squats, push-ups, runs on balance beams, among others (Figure 1B). In the men's competition, athletes must overcome 20 obstacles along the course, while in the women's competition four obstacles were excluded: rope ladder, sloping wall with rope, four steps of beams, and vertical ladder. In addition, in the women's event, boxes with $30 \mathrm{~cm}$ in height are placed to help overcome three obstacles: Irish table, pit, and the assault wall II. For more obstacle details, we suggest the reading of the military pentathlon regulations ${ }^{7}$. The world record for the women's event is 2:10.9 min, while the Brazilian record is 2:22.1 min, also for soldier Naiana.

The obstacle swimming, a high-intensity event with short duration (from 24"30 to 33"00 for men, and 28"00 to 39 "00 for women - high-level athletes), requires the athlete's muscle power to overcome obstacles and maintain a 


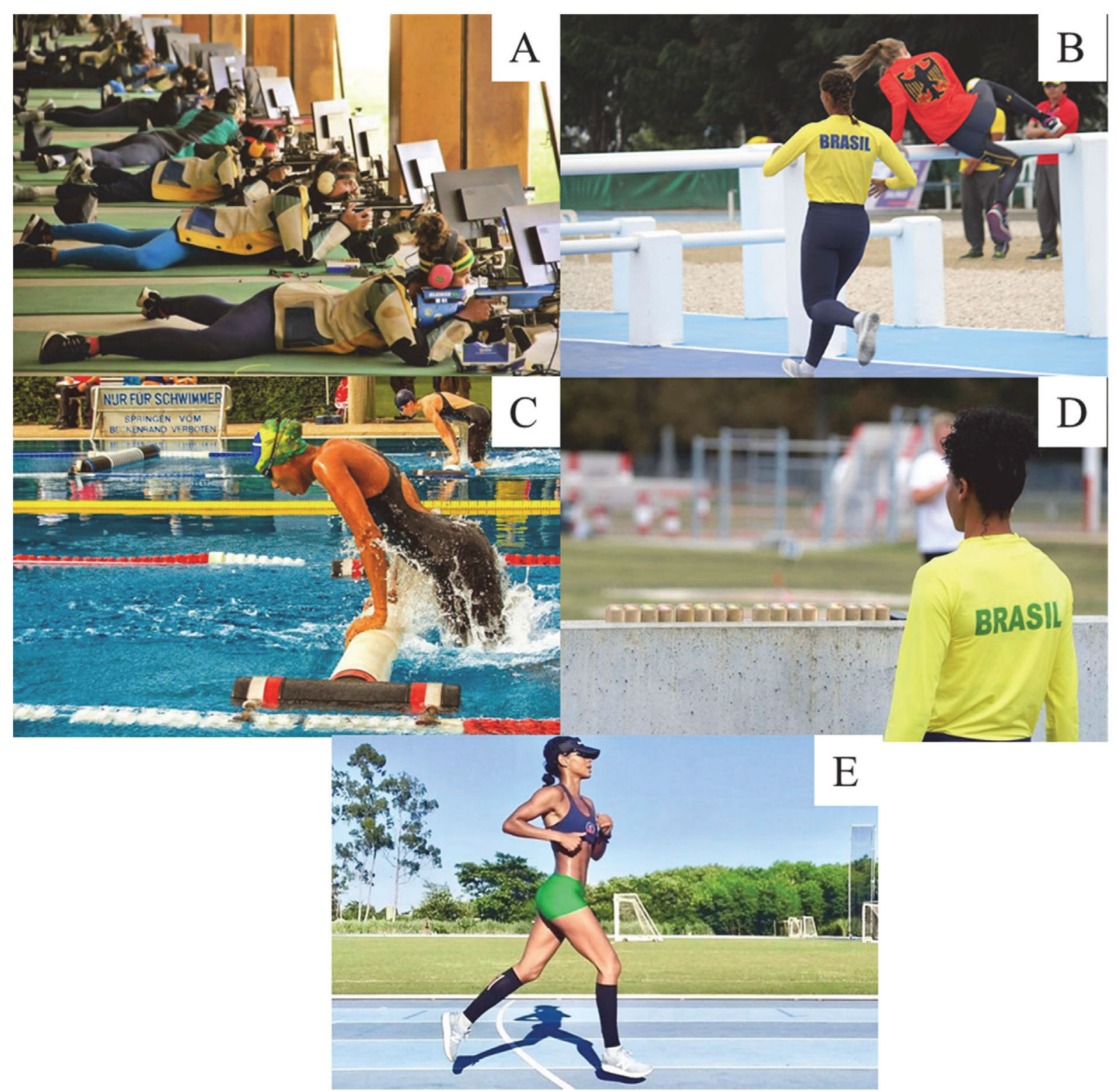

Figure 1 - Military Pentathlon Female athletes during A) shooting; B) obstacle run; C) obstacle swimming; D) throwing; and E) cross-country race events.

vigorous rhythm of strokes and kicks. In this event, athletes must perform $50 \mathrm{~m}$ of swimming while overcoming four different obstacles distributed throughout the pool (Figure 1C). There are no differences between male and female competition, except for the conversion into PP criterion. Soldier Naiana was the world champion of this event for six times and is the current world record holder with a time of $27.2 \mathrm{~s}$.

The grenade throwing (Figure 1D) is divided into two stages. In the first, a precision throw is performed, a mix of upper limb power, perfect control (control) of the motor gesture (technical factor) in addition to concentration, adequate activation, and anxiety control. In a second moment, the throw is performed to the longest distance, an activity that requires maximum power from the upper limbs. When throwing a grenade, the differences between the male and female competitions are in the weight of the grenades (575 g for men and $375 \mathrm{~g}$ for women) and the distances between the precision circles. The Brazilian female record in this competition is 185.7 points, obtained by the 3rd Sgt Tatiane, of the Brazilian Army, and in 2018, in the 65th World Military Pentathlon Championship, soldier Naiana was the champion of this competition with 177.2 points.

Finally, we have the 4 and $8 \mathrm{~km}$ cross-country race for women and men, respectively. This event presents pre- 
dominantly aerobic characteristics, in which it is necessary to maintain a high-intensity pace to become a competitive athlete (Figure 1E). The female Brazilian record holder in the cross-country race is the 3rd Sgt Camila Campanhola, from the Brazilian Army, with a time of $14 \min 26 \mathrm{~s}$.

It should be noted that the five events are distributed in three days of competition, and there may be one or two events per day ${ }^{7}$. Training to achieve excellence in a multievent modality with such diverse technical, physical, and psychological characteristics is not an easy task. As it was possible to observe from the description of the characteristics of each event, it is necessary to develop athletes' aerobic and anaerobic capacity, lower and upper limb muscle power, balance, coordination, agility, in addition to other skills such as concentration and emotional balance.

Therefore, it is common for coaches to plan microcycles with accumulated training volumes and with high amounts of weekly sessions (e.g. 15 training sessions per week). In addition to specific training, it is important to plan and constantly carry out strength training, which will be the driving force behind sports performance, particularly those associated with strength and power (as obstacle swimming, throwing, and obstacle run).

Such high loads of physical and psychological demands make the preparation and evolution of practitioners extremely stressful. Thus, during the planning of micro and mesocycles, the physical trainer must be able to adjust the relationship between volume and intensity of training for the five events of military pentathlon, in addition to precisely adjusting the time which will be dedicated to regenerative work. Only the proper balance between applied load and recovery time will allow supercompensation to occur and improve the athlete's performance ${ }^{12}$.

\section{Scientific research and the female military pentathlon}

The literary search on PubMed/Medline, Scielo, and Scholar Google databases retrieved 271 records. Eighteen were excluded because they were duplicated, and four articles were added due to authors' knowledge. After title and summary screening, 235 records were excluded and 22 records full-text were completely read. While reading the full-texts, six findings were excluded because they were abstracts or preliminary studies from another fulltext record also selected, one because the sample included only male athletes and another one because men and women were analyzed together. Finally, 14 studies were included in this review (Figure 2).

A short description of each of the 14 articles reviewed $^{8,13-25}$ is presented in Table 2 in chronological order, along with their features and results. Publication date ranged from 2007 to 2021, showing that female military pentathlon is a very recent field of study (14 years, with $64.29 \%$, of the studies published in the last five years). From the 14 studies, 10 compared women and men, but in three of them, no statistical test was applied. The other four comprised only female athletes. The investigated outcomes were psychological, anthropometric, and cardiopulmonary variables, muscle power, blood lactate, skin temperature, energy expenditure, nutrients intake, performance, and prevalence of injury. Sample age was similar among major studies, varying from 24.4 to 29.3 years old. The other two papers presented extreme lower ${ }^{20}$ and higher ${ }^{23}$ values. Finally, from the 14 studies, 11 were cross-sectional and the other three presented a pre-post study design. Only five from the 14 records were full-text articles (two monographs, five abstracts, one book chapter, one full-text record not published in a scientific journal). There was no experimental or quasi-experimental study, corroborating the scarcity of interventional studies that could contribute to the election of the best training interventions with female military pentathlon athletes.

The first record included in our review is a report about the frequency of injury in the $4^{\text {th }}$ World Military Games. Patra et al. ${ }^{13}$ presented a significantly higher prevalence of injury for men in military pentathlon athletes. Maybe the higher height of some obstacles in the obstacle run event could explain this greater prevalence of injury in men. Four years later, in the same year of the 5th Word Military Games, which took place in Brazil (2011), Genial et al. ${ }^{14}$ compared pre-competitive anxiety between men and women using the Competitive State Anxiety Inventory2 (CSAI-2). They found the female athletes presented higher values for cognitive and somatic anxiety. In the next year (2012), the same research group published the results of coping skills ${ }^{15}$ of those athletes and found that women presented lower values of peaking under pressure. All other copying skills were similar between men and women. It is important to notice, although, the presence of some confounding factors in both papers: male athletes presented significantly more years of training and each group comprised both military pentathlon and shooting athletes (Table 2).

In 2015 , the year of the $6^{\text {th }}$ WMG, other two studies were found, both published in a scientific event proceedings ${ }^{16,17}$. Batista and Mainenti ${ }^{16}$ found strong and very strong correlations among cross-country event performance and two variables (Velmax and $\mathrm{vVO}_{2} \max$ ) of a cardiopulmonary exercise test (Table 2). Interestingly, the same variables presented significant correlations in another study from our institution (Escola de Educação Física do Exército - EsEFEx), in a men sample ${ }^{26}$. Correia and Charbel ${ }^{17}$ studied the effect of the drop height in variables of the drop jump in a force platform. They observed some correlations among drop height, flight time, and ground contact time. Coefficients were not presented. These two studies present an important limitation: they are not full-text documents. In fact, the full-text of the first one ${ }^{16}$, from our research group, was submitted 


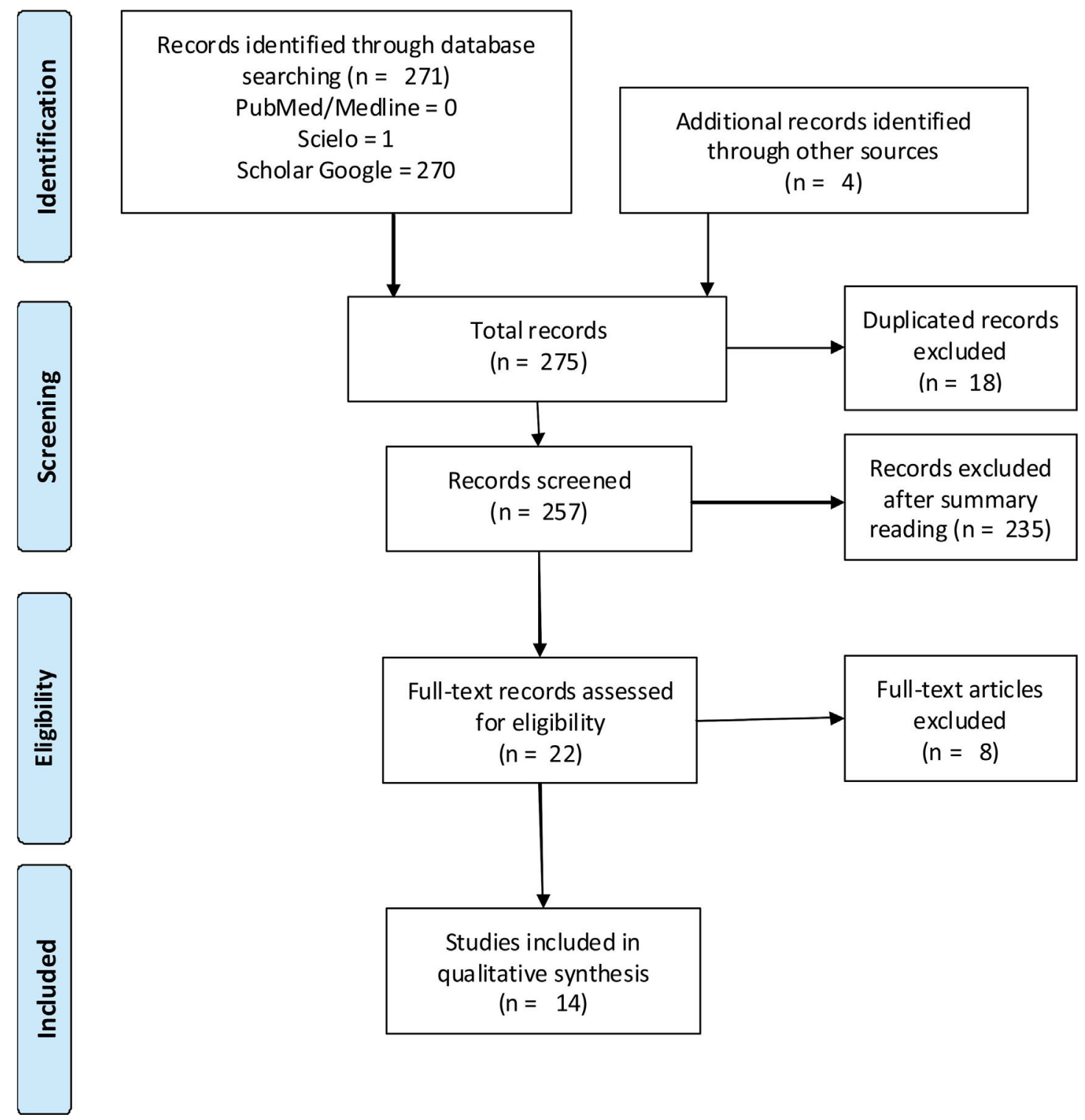

Figure 2 - Flow diagram on the study selection process.

previously and we are awaiting the decision of the journal's editor.

Another study from our group, with the same sample (female athletes that participated in the $6^{\text {th }} \mathrm{WMG}$ ), was published in 2017, investigating the association between military pentathlon performance and anthropometric data ${ }^{8}$. We did some clusters of athletes considering performance, body composition, and body size variables. We identified that all the athletes in the cluster of better body composition were in the cluster of better performance, indicating a relationship between body composition and military pentathlon performance (which were registered in points of pentathlon). It is noteworthy the low values of body fat found in these female athletes. The body fat percentage median of the studied sample was $9.32 \%$, ranging from 6.31 to $15.61 \%$. The third quartile (which comprises $75 \%$ of data) is lower than the minimum value of the "excellent" classification $^{27}$. This scenario increases de risk of the "female athlete triad", more recently termed "relative energy deficiency in sport" (RED-S) ${ }^{28}$. It started with a low energy availability due to different reasons, including high training volume, which is often observed in military pentathlon athletes, and/or insufficient energy uptake $(\operatorname{diet})^{28,29}$. Additionally, some other military duties include episodes of energy deficiency, such as field exercises $^{30}$, increasing the triad/RED-S risks. If not controlled, consequences for health and performance could appear, like menstrual and bone disorders ${ }^{28,29}$. Professionals of the technical committee must be aware of the signs and symptoms of this clinical condition to prevent or treat as soon as possible. 
Table 2 - Reviewed articles $(n=14)$ and main results.

\begin{tabular}{|c|c|c|c|c|}
\hline Reference & Year & Sample & Outcomes & Study design and Main results \\
\hline Patra et $\mathrm{al}^{13}$ & 2007 & $\mathrm{n}=51$ women, 151 men (MP athletes) & Prevalence of injury during $4^{\text {th }} \mathrm{WMG}$ & Cross-sectional \\
\hline \multirow[t]{3}{*}{ Full-text report } & & Participants of $4^{\text {th }} \mathrm{WMG}$ & & Women: lower prevalence of injury \\
\hline & & Countries in $4^{\text {th }} \mathrm{WMG}$ & & (7.8 vs. $24.5 \%)$ \\
\hline & & Age: NR & & \\
\hline Genial et al. ${ }^{14}$ & 2011 & $\mathrm{~N}=7$ women, 9 men (MP athletes) & Competitive State Anxiety Inventory-2 & Cross-sectional \\
\hline \multirow[t]{5}{*}{ Full-text article } & & Participants of $5^{\text {th }} \mathrm{WMG}$ & $(\mathrm{CSAI}-2)$ & Cognitive anxiety: women $>$ men \\
\hline & & Brazil & - Cognitive anxiety & Somatic anxiety: women > men \\
\hline & & Age: $27.9 \pm 6.4$ (women)* & - Somatic anxiety & Self-confidence: women $=$ men \\
\hline & & $29.8 \pm 5.2(\mathrm{men})^{*}$ & • Self-confidence & \\
\hline & & & Higher values, higher anxiety. & \\
\hline Cotian et al. ${ }^{15}$ & 2012 & $\mathrm{~N}=7$ women, 9 men (MP athletes) & Athletics Coping Skills Inventory (ACSI-28) & Cross-sectional \\
\hline \multirow[t]{7}{*}{ Full-text article } & & Participants of $5^{\text {th }} \mathrm{WMG}$ & • Coping with Adversity & Peaking under pressure: women $<$ men \\
\hline & & Brazil & - Peaking under Pressure & Other coping skills: women = men \\
\hline & & Age: $27.8 \pm 3.4$ (women)* & - Goal Setting/Mental Preparation & \\
\hline & & $30.1 \pm 5.3$ (men)* & • Concentration & \\
\hline & & & • Freedom from Worry & \\
\hline & & & - Confidence and Achievement Motivation & \\
\hline & & & $\begin{array}{l}\bullet \text { Coachability } \\
\text { Higher values, a higher coping skill. }\end{array}$ & \\
\hline Batista and Mainenti ${ }^{16}$ & 2015 & $\mathrm{~N}=6$ women (MP athletes) & $\begin{array}{l}\text { Cardiopulmonary variables during progressive exer- } \\
\text { cise }\end{array}$ & Cross-sectional \\
\hline \multirow[t]{6}{*}{ Abstract } & & Participants of $6^{\text {th }}$ WMG & $\bullet \mathrm{VO}_{2} \max$ & Very strong correlation \\
\hline & & Brazil & - $\mathrm{vVO}_{2} \max$ & $\mathrm{CCPP}$ and $\mathrm{vVO}_{2} \max (\mathrm{r}=0.98)$ \\
\hline & & Age: $27.5[25.0 ; 29.3]^{* *}$ & - $\mathrm{VO}_{2} \mathrm{VT} 1$ & Strong correlation \\
\hline & & & $\bullet$ VelV1 & CCPP and Velmax $(r=0.79)$ \\
\hline & & & - Velmax & \\
\hline & & & Cross country running performance (CCPP) & \\
\hline Correia and Charbel $^{17}$ & 2015 & $\mathrm{n}=4$ women (MP athletes) & Drop jump variables & Cross-sectional \\
\hline \multirow[t]{4}{*}{ Abstract } & & Participants of $6^{\text {th }} \mathrm{WMG}$ & • Drop height & Correlations between \\
\hline & & Brazil & - Flight time & Drop height and flight time \\
\hline & & Age: $29.3 \pm 2.5^{*}$ & - Ground contact time & Drop height and ground contact time \\
\hline & & & Obstacle run performance & \\
\hline
\end{tabular}


Table 2 - continued

\begin{tabular}{|c|c|c|c|c|}
\hline Reference & Year & Sample & Outcomes & Study design and Main results \\
\hline$\overline{\text { Schramm et al. }}{ }^{8}$ & 2017 & $\mathrm{n}=5$ women (MP athletes) & $\begin{array}{l}\text { Body size variables (shoulder width, arm span, hand } \\
\text { length, arm length, knee height, and others) }\end{array}$ & Cross-sectional \\
\hline \multirow[t]{3}{*}{ Full-text article } & & Participants of $6^{\text {th }} \mathrm{WMG}$ & $\begin{array}{l}\text { Body composition variables (abdominal girth, arm } \\
\text { muscle circumference, skinfold sum, body fat, FFM, } \\
\text { and others) }\end{array}$ & $\begin{array}{l}\text { Cluster of athletes with better performance comprises the } \\
\text { cluster of athletes with better body composition }\end{array}$ \\
\hline & & Brazil & PP of each MP event & \\
\hline & & Age: $28[25 ; 29]^{* *}$ & & \\
\hline Neves e Mainenti ${ }^{18}$ & 2018 & $\mathrm{n}=5$ women, 5 men (MP athletes) & Body fat (\%) & Cross-sectional \\
\hline \multirow[t]{5}{*}{ Book chapter } & & Participants of $6^{\text {th }} \mathrm{WMG}$ (women) & PP of each MP event & Body fat (\%) vs PP of each MP event: \\
\hline & & Participants of $64^{\text {th }}$ WMPC (men) & & Women: weak, fair, and strong correlations \\
\hline & & Brazil & & ( $\mathrm{r}$ ranging from 0.08 to 0.75 ) \\
\hline & & Age: $26.4 \pm 2.6$ (women)* & & Men: weak and fair correlations \\
\hline & & $27.0 \pm 2.8$ (men) $)^{*}$ & & ( $\mathrm{r}$ ranging from 0.02 to 0.49 ) \\
\hline Neves $^{19}$ & 2019 & $\mathrm{n}=27$ women, 57 men (MP athletes) & Sargent jump test (SJT) & Cross-sectional \\
\hline \multirow[t]{6}{*}{ Abstract } & & Participants of $64^{\text {th }}$ WMPC & Relative throwing distance (RTD) & Women: lower values SJT, RTD, ORP \\
\hline & & Countries in $64^{\text {th }} \mathrm{WMPC}$ & Obstacle run performance (ORP) & SJT and RTD $v s$ performance \\
\hline & & Age: $20-35^{* * *}$ & Obstacle swimming performance & Women: weak, fair, and strong correlations \\
\hline & & & Cross country performance & ( $\mathrm{r}$ ranging from -0.616 to -0.138 ) \\
\hline & & & & Men: weak and fair correlations \\
\hline & & & & ( $\mathrm{r}$ ranging from -0.324 to -0.086 ) \\
\hline Leite et al. ${ }^{20}$ & 2019 & $\mathrm{n}=4$ women, 6 men (MP athlete cadets) & Blood lactate & Pre-post (OR) \\
\hline \multirow[t]{2}{*}{ Full-text article } & & AMAN cadets & & Higher values after OR \\
\hline & & Age: $22.0 \pm 2.8^{*}$ & & Women: lower values than men \\
\hline Souza $^{21}$ & 2019 & $\mathrm{n}=4$ women, 9 men (MP athletes) & Dietary energy intake (DEI) & Cross-sectional \\
\hline \multirow[t]{7}{*}{ Monograph } & & 2019 Brazilian team & Total daily energy expenditure (TDEE) & For both groups mean values: \\
\hline & & Age: $28.9 \pm 3.9$ (women)* & DEI/TDEE (\%) & $\mathrm{CHO}$ intake lower than recommended \\
\hline & & $26.1 \pm 2.2(\mathrm{men})^{*}$ & CHO, LIP, PTN intake & PTN and LIP as recommended \\
\hline & & & VitC, $\mathrm{Ca}$, Iron intake & $\mathrm{Ca}$ intake lower than recommended \\
\hline & & & & Iron intake higher than recommended \\
\hline & & & & VitC intake lower than recommended \\
\hline & & & & $\begin{array}{l}\text { Women: higher DEI, lower TDEE, higher DEI/TDEE } \\
\text { (just descriptive, no statistical tests applied) }\end{array}$ \\
\hline Souza Filho ${ }^{22}$ & 2020 & $\mathrm{n}=5$ women, 4 men (MP athletes) & Dietary energy intake (DEI) & Cross-sectional \\
\hline Monograph & & 2020 Brazilian team & Energy expenditure on exercise (EEE) & Women: lower DEI, EEE, TDEE \\
\hline
\end{tabular}


Table 2 - continued

\begin{tabular}{|c|c|c|c|c|}
\hline Reference & Year & Sample & Outcomes & Study design and Main results \\
\hline & & Age: $24.4 \pm 3.9$ (women)* & Energy availability (EA) & (just descriptive, no statistical tests applied) \\
\hline & & $26.5 \pm 1.7$ (men)* & Total daily energy expenditure (TDEE) & $\begin{array}{l}\text { Women EA: } 80 \% \text { lower than minimal recommended } \\
\text { values }\end{array}$ \\
\hline & & & & Men EA: $100 \%$ lower than minimal recommended value \\
\hline Santos-García et al ${ }^{23}$ & 2021 & $\mathrm{n}=7$ women, 7 men (MP athletes) & $50 \mathrm{~m}$ freestyle swimming (FS) performance & Pre-Post (50 m FS or OS) \\
\hline \multirow[t]{4}{*}{ Full-text article } & & Spanish team & $50 \mathrm{~m}$ obstacle swimming (OS) performance & OS higher BL (both sexes) \\
\hline & & Age: $33.7 \pm 5.5$ (women)* & Blood lactate (BL) after FW and OS & BL: women $=$ men after $\mathrm{FS}$ or $\mathrm{OB}$ \\
\hline & & $33.4 \pm 3.7$ (men)* & & Fair correlations between FS and OS: \\
\hline & & & & Women: 0.40 ; men: 0.60 \\
\hline Mello et al. ${ }^{24}$ & 2021 & $\mathrm{n}=7$ women, 9 men (MP athletes) & Skin temperature (Tsk) at lower limbs ROIs & Pre-Post (OR) \\
\hline \multirow[t]{2}{*}{ Abstract } & & 2021 Brazilian team & & Post OR: higher Tsk (both sexes) \\
\hline & & Age: $26.3 \pm 3.3^{*}$ & & Tsk: lower for women, especially post OR \\
\hline Loyola et al. ${ }^{25}$ & 2021 & $\mathrm{n}=48$ women (MP athletes) & PP of each MP event & Cross-sectional \\
\hline \multirow[t]{3}{*}{ Abstract } & & Participants of $7^{\text {th }} \mathrm{WMG}$ & Final $7^{\text {th }}$ WMG position standing & $\begin{array}{l}\text { Correlations among final standing and PP of each MP } \\
\text { event: }\end{array}$ \\
\hline & & Countries in $7^{\text {th }} \mathrm{WMG}$ & & Weak to fair: obstacle run and shooting \\
\hline & & Age: NR & & Strong: cross country, obstacle swimming, throwing \\
\hline
\end{tabular}

* mean \pm standard deviation; **median $\left[1^{\text {st }}\right.$ quartile; $3^{\text {rd }}$ quartile $] ; * *$ minimum - maximum; AMAN - Academia Militar das Agulhas Negras; BL - blood lactate; Ca $=$ Calcium; CCPP - Cross country points of pentathlon; $\mathrm{CHO}$ = carbohydrate; DEI = dietary energy intake; EEE - Energy expenditure on exercise; EA = Energy availability; FFM = fat free mass; FS = freestyle swimming; LIP = lipids; MP = military pentathlon; $\mathrm{NR}=$ not reported; $\mathrm{OS}=$ obstacle swimming; $\mathrm{OR}=$ obstacle run; $\mathrm{PP}=$ points of pentathlon; $\mathrm{PTN}=$ protein; $\mathrm{ROI}=$ region of interest; TDEE $=$ total daily energy expenditure; Tsk $=$ skin temperature; Velmax $=$ maximum velocity; VelV1 = velocity at the first ventilator threshold; $\mathrm{VitC}=$ vitamin $\mathrm{C} ; \mathrm{VO}_{2} \max =\operatorname{maximum}$ oxygen uptake; $\mathrm{vVO} \mathrm{O}_{2}$ max $=$ lowest velocity at which $\mathrm{VO}_{2}$ plateau is observed;

$\mathrm{VO}_{2} \mathrm{VT} 1=$ oxygen uptake at the first ventilator threshold; $\mathrm{WMG}=$ world military games; $\mathrm{WMPC}=$ world military pentathlon championship. 
In the next year, 2018, we published a chapter about anthropometric, psychological, and performance of military athletes ${ }^{18}$, and data concerning military pentathlon showed some significant correlations between body fat percentage and the performance in each military pentathlon event, with higher coefficient values for women.

A similar result was obtained for correlations among upper and lower limb explosive strength and athletic performance, presented by Neves ${ }^{19}$ in the CISM International Symposium. Coefficients were higher for the bivariate correlations with women data, compared with men's. This author used an interesting variable for upper limb power: the relative throwing distance (RTD), calculated as

$$
R T D=\frac{\text { maximal throwing distance } \times \text { projectile mass }}{\text { total body mass }},
$$

instead of using only the throwing total distance.

This outcome (RTD) ensures a fairer comparison between women and men. In fact, if detailed body composition measurements are available, using muscle mass instead of total body mass would represent an even better variable. Future studies are encouraged to use it when comparing physical fitness and characteristics between women and men.

In 2019, Leite et al. ${ }^{20}$ published the first paper issuing a biochemical variable in female military pentathlon athletes. They showed a great increase in blood lactate after obstacle run performance, both for women and men, with lower values always for women. The lactate increase was expected since this military pentathlon event is a very high-intensity physical activity, but also confirms the anaerobic as the main metabolism used during the obstacle run. Santos-García et al. ${ }^{23}$ also measured blood lactate, but after obstacle and freestyle swimming, and found no sex main effect (two-way ANOVA). Nevertheless, the type of swimming main effect was significant, with higher values of blood lactate after obstacle swimming. Only these two studies analysed biochemical measures. Athletes of other disciplines consistently show increases in muscle damage biomarkers after championships ${ }^{31,32}$, sometimes with lower values of these biomarkers in female athletes ${ }^{31}$, which is explained by estrogen presence ${ }^{33}$ and lower total muscle mass in women. Future studies are encouraged assessing these biomarkers, using muscle mass corrections whenever possible.

Recently, other two records were found in our review issuing nutrition data and military pentathlon athletes $^{21,22}$. Although no statistical test was applied, it could be noticed that many athletes did not reach the recommended values, and that the energy intake did not always match the energy expenditure ${ }^{21,22}$, causing low values of energy availability ${ }^{22}$. This fact added to the low adiposity values observed by Schramm et al. ${ }^{8}$ and Neves and Mainenti ${ }^{18}$ are frequently observed in women with
RED-S/female athlete triad, showing that female military pentathlon athletes seem to be at risk of this syndrome.

Finally, two studies from our group ${ }^{24,25}$ were approved in international scientific events and their presentations are scheduled for next month. Mello et al. ${ }^{24}$ used infrared thermography pre and post-one obstacle run event. The increase of temperature after an obstacle run is probably associated with its high-intensity characteristic that leads to great metabolic stress requested by muscles. Another interesting finding of this study is the difference in skin temperature between female and male athletes, which may be associated with the fact that female athletes did not perform four obstacles: rope ladder, a sloping wall with rope, four steps of beams, and vertical ladder, all related to jumping and impact absorption, which leads to the absorption of energy necessary for movement.

Infrared thermography is one of the methods for the assessment of skin temperature that has been growing in the sports area as a non-expensive, non-evasive and safe method. From the skin temperature, it is possible to assess the differences in heat in different parts of the body, and correlate them with physiological processes, vascular changes, injuries, or muscle dysfunctions, before, during, and after the physical exercise ${ }^{34}$. In the sports field, infrared thermography has been widely used for thermoregulation analysis, injury prevention, and training load control. Based on it, in the last two years, some correlational studies have been developed with military pentathlon athletes analysing the skin temperature and performance in a master's thesis of a military pentathlete ${ }^{35}$ supervised by one of the authors of this review. New papers must be available in the next years, improving this interesting field of study.

The other study approved in international scientific event investigated the correlation among final $7^{\text {th }}$ WMG position standing and each military pentathlon event ${ }^{25}$. It shows that the shooting and obstacle run events are less correlated with final position standing when compared to cross country, obstacle swimming, and throwing. The low correlation with shooting is somehow explained by the technological advances in weapons and equipment that bring the results of this event very close to the maximum possible score.

The search showed a prevalent involvement of our institution, Escola de Educação Física do Exército (EsEFEx) in national publications. The "almost centenary" EsEFEx (it will complete 100 years in 2022) is one of the pioneer institutions in the constitution of undergraduate courses in Physical Education in Brazil, and since the middle of the last century (1963) military pentathlon is a regular content of our courses. In 1960, EsEFEx hosted for the first time an international championship in the modality: the III International Military Pentathlon Champion$\operatorname{ship}^{36}$. These historic data highlight the great relevance of this discipline for EsEFEx since the 60'. However, it was only in 2015 that we began to develop more systematic 
research in this field of study, through a movement of academic growth, including civilian professors with doctorates and military personnel from various posts engaged in the academic area. Another factor that contributed to this advance (which is still incipient) was the support and interest of the Comissão de Desportos do Exército (CDE) in the development of research with male and female military pentathlon athletes.

It is worth mentioning a recent fact that occurred at EsEFEx that increases the prospect of growth in this theme, both in terms of performance and in scientific research development. In 2016, for the first time, a female sergeant enrolled the EsEFEx Physical Education Monitor Course and since then other five military women have participated in the course (2017 - 02; 2018 to 2020 - 0; 2021 $3)$. Despite including several other contents, the military pentathlon is present in this course, and it is certainly an opportunity for the military to know, practice, and encourage their practice in the military organizations they will serve throughout Brazil. The Physical Education Instructor course at EsEFEx (equivalent to the Bachelor's Degree in the civil scope) has not yet received women in its student body, with an expected female lieutenant for 2022.

About the limitations of the present review, we included records only in English and Portuguese. Maybe the inclusion of Mandarin would improve our results. Nevertheless, there are still few studies with female military pentathlon, particularly research with manipulation of interventions and independent factors.

\section{Conclusion}

Scientific research with female military pentathlon is still incipient. After reviewing the 14 records, some studies' data showed that professionals should be aware of athletes' body composition and nutritional data to prevent the female athlete triad, more recently termed relative energy deficiency in sports (RED-S). It seems that female military pentathlon athletes present a high risk to develop this clinical condition. We also noticed that the predominance of anaerobic metabolism was confirmed in both obstacle run and obstacle swimming, with a lower increase for women in obstacle run, but not in obstacle swimming, in which the increase was similar to men counterparts. The obstacle run causes some different impacts for women, as less increase in skin temperature, especially because they perform a less stressful track (minus four obstacles and height support in three obstacles with box positioning). It was also observed that anthropometric, muscle power, and cardiopulmonary variables are well correlated with athletic performance for female athletes.

For future research, we recommend studies including prevalence/incidence and type of athletes' injuries throughout a season or competition; cell injury and oxidative stress biomarkers modifications after competitions or a specific applied training; samples with different competitive levels, since the findings are mostly of high-level competition athletes; larger sample sizes; and especially experimental studies testing different physical training interventions.

\section{Acknowledgments}

We would like to thank CADESM/DECEx (Coordination for Evaluation and Improvement of Military Higher Education / Department of Education and Culture of the Army), which partially supported the present study. We would also like to acknowledge the Brazilian Army Sports Commission (CDE) for the cooperation and motivation for the studies with military pentathlon.

\section{References}

1. International Olympic Committee. Gender equality through time: at the Olympic Games, 2020. Available from: https:// olympics.com/ioc/gender-equality/gender-equality-throughtime/at-the-olympic-games. [Accessed 19th October 2021].

2. PiccirilloH. Message of the CISM President on the occasion of the International Women's Day 2021, 2021. Available from: https://www.milsport.one/news/march-2021-0321/messageof-the-cism-president-on-the-occasion-of-the-internationalwomen-s-day-2021 [Accessed 25th October 2021].

3. Braun LA, Kennedy HP, Sadler LS, Dixon J. Research on U.S. military women: recruitment and retention challenges and strategies. Mil Med. 2015;180(12):1247-55. doi.

4. Silva VB, Vasques LV. A inserção do segmento feminino na linha de ensino militar bélica do Exército Brasileiro e os seus possíveis reflexos para a Academia Militar Das Agulhas Negras - AMAN. Trabalho de Conclusão de Curso [Curso de Gestão, Assessoramento e Estado Maior], Escola de Formação Complementar do Exército; 2020.

5. Brasil. Presidência da República. Casa Civil. Subchefia para Assuntos Jurídicos. Lei no 12.705, de 08 de agosto de 2012. Aprova o ingresso na linha militar bélica de ensino a candidatos do sexo feminino. Available from: http://www.pla nalto.gov.br/ccivil_03/_Ato2011-2014/2012/Lei/L12705. htm. [Accessed 25th May 2015].

6. Estado Maior do Exército. Portaria No 493-EME, de 9 de novembro de 2016. Aprovar a Diretriz para os Desportos no Exército para o ano de 2017 (EB20-D-01.033). Available from: http:/www.cidex.ebmil.br/images/Documentos/ eple_eo/be50-16.pdf\#page $=15$ [Accessed $25^{\text {th }}$ October 2021].

7. Conseil International du Sport Militaire. Military pentatlon regulations, 2020. Available from: https://www.milsport. one/sports/military-pentathlon [Accessed 19th October 2021].

8. Schramm FF, Bastos LFV, Mainenti MRM. Atletas de pentatlo militar feminino com melhor composição corporal apresentam melhor desempenho na modalidade. J. Phys. Educ. 2017;28:e2806. doi.

9. Conseil International du Sport Militaire. Competition history, 2018. Available from: https://www.milsport.one/ sports/military-pentathlon [Accessed 19 October 2021]. 
10. Mon-López D, Zakinthinaki MS, Cordente CA, Garcia Gonzales J. The relationship between pistol Olympic shooting performance, handgrip, and shoulder abduction strength. J Hum Kinet. 2019;69:39-46. doi

11. Leite DG, Baptista MT, Machado FA, Marinho PC. Análise do desempenho competitivo na pista de pentatlo militar por meio da biomecânica. R Min Educ Física. 2015;23(1):7-21.

12. Dias HM, Zanetti MC, Figueira Jr AJ, Marin DP, Montenegro CGAP, Carneiro YM, et al. Evolução histórica da periodização esportiva. Corpo Consciência 2016;20(1):67-79.

13. Patra AK, Grargava P, Grewal VS. Medical cover plan - 4th World Military Games, 2007. Available From: https://cite seerx.ist.psu.edu/viewdoc/download?doi=10.1.1.625.25\&re $\mathrm{p}=\mathrm{rep} 1 \&$ type $=$ pdf [Accessed: 25 th October 2021].

14. Genial LO, Cotian MS, Fortes MSR. Avaliação psicométrica de atletas militares participantes dos $5^{\circ}$ Jogos Mundiais Militares. R Min Educ Fís. 2011;19(3):7-18.

15. Cotian MS, Genial LO, Fortes MS. Avaliação das habilidades psicológicas de coping em atletas militares participantes dos $5^{\circ}$ Jogos Mundiais Militares. J Phys Ed. 2012;81 (154):13-17. doi

16. Batista HB, Mainenti MR. Velocidade de platô de VO2 e velocidade máxima: variáveis cardiopulmonares potencialmente importantes na seleção e treinamento de atletas de pentatlo militar feminino. J Phys Ed. 2015;84(1):35.

17. Correia RC, Charbel M. Altura de queda ótima em treinamento pliométrico para equipes de pentatlo militar. J Phys Ed. 2015;84(1):14.

18. Neves AN, Mainenti MRM. Estudos em antropometria e psicologia do esporte acerca do desempenho de atletas militares - contribuições da Escola de Educação Física do Exército - EsEFEx. In: Pesquisa Científica em Instituições Militares. Rio de Janeiro, Centro de Estudos de Pessoal e Forte Duque de Caxias; 2018. p. 221-247.

19. Neves EB. Explosive force production in military pentathlon athletes. CISM 2019 International Symposium Abstract. Available from: https://www.researchgate.net/publication/ 322821896_Explosive_force_production_in_military_pen tathlon athletes [Accessed 25th October 2021].

20. Leite DG, Moraes Filho JEM, Mello DB, Wechinewsky FM. Nível de lactato sanguíneo, em homens e mulheres, verificados antes e após a execução da pista de pentatlo militar. Revista Agulhas Negras. 2019;3(3):126-31.

21. Souza DCA. Perfil dietético de atletas da seleção brasileira de pentatlo militar. Trabalho de Conclusão de Curso [Bacharelado em Educação Física], Escola de Educação Física do Exército, Rio de Janeiro; 2019.

22. Souza Filho MA. Ingestão alimentar e disponibilidade de energia nos atletas da seleção brasileira de pentatlo militar no ano de 2020. Trabalho de Conclusão de Curso [Bacharelado em Educação Física], Escola de Educação Física do Exército, Rio de Janeiro; 2020.

23. Santos-García DJ, Aznar JP, Fernández FA, Yustres I, Barragán R, Mayoralas FG-M. Relationship between $50 \mathrm{~m}$ freestyle swimming and $50 \mathrm{~m}$ obstacle swimming performance in military. Med Sport. 2021;74(1):35-42. doi.

24. Mello D, Dias T, Romão W, Neves EB, Pierre JR GL, Rosa $\mathrm{G}$, et al. The influence of military pentathlon obstacle run on athletes' skin temperature. CISM 2021 International Symposium Abstract. In press.
25. Loyola MVM, Mainenti MRM, Santos LVC, Miarka B. Pentatlo militar: qual a prova determinante no resultado final do campeonato mundial feminino 2019? J Phys Ed. 2021; 90(4 Suplemento Especial), S35.

26. Batista LB, Mello DB, Garcia RCF, Sales TD, Mainenti MRM. Correlação de variáveis do teste de esforço cardiopulmonar com o desempenho na corrida através campo de atletas de elite do sexo masculino de pentatlo militar do Brasil. J Phys Ed. 2019;88(4):S1-26.

27. Jackson AS, Pollock ML, Ward A. Generalized equations for predicting body density of women. Med Sci Sports Exerc. 1980;12(3):175-82.

28. De Souza MJ, Koltun KJ, Etter CV, Southmayd EA. Current status of the female athlete triad: update and future directions. Curr Osteoporos Rep. 2017;15(6):577-87. doi

29. Nazem TG, Ackerman KE. The female athlete triad. Sports Health. 2012;4(4):302-11. doi

30. O'Leary TJ, Wardle SL, Greeves JP. Energy deficiency in soldiers: the risk of the athlete triad and relative energy deficiency in sport syndromes in the military. Front Nutr. 2020;7:142. doi

31. Danielsson T, Carlsson J, Schreyer H, Ahnesjo J, Ten Siethoff L, Ragnarsson T, et al. Blood biomarkers in male and female participants after an Ironman-distance triathlon. PLoS ONE. 2017;12(6):e0179324. doi.

32. Mello D, Neves EB, Romão W, Santos A, Farias F, Dias T, et al. Acute physiological responses during a Brazilian endurance triathlon race. Motricidade. 2020;16(4):411-19.

33. Kendall B, Eston R. Exercise-induced muscle damage and the potential protective role of estrogen. Sports Med. 2002;32:103-123.

34. Moreira DG, Costello JT, Brito CJ, Adamczyk JG, Ammer $\mathrm{K}$, Back AJ, et al. Thermographic imaging in sports and exercise medicine: a Delphi study and consensus statement on the measurement of human skin temperature. J Thermal Biol. 2017;69,155-62.

35. Dias TS. Associação entre composição corporal, marcadores fisiológicos, temperatura da pele e desempenho em atletas na pista de Pentatlo Militar. Dissertação [Programa de Pós-Graduação em Ciências do Exercício e do Esporte], Instituto de Educação Física e Desportos, do Rio de Janeiro; 2021.

36. Ramos JJ. Escola de educação física do exército. A Defesa Nacional. 1966;608:31-60.

\section{Corresponding author}

Míriam Raquel Meira Mainenti. Escola de Educação

Física do Exército, Rio de Janeiro, RJ, Brazil.

E-mail: miriam.mainenti@hotmail.com.

Manuscript received on October 30, 2021

Manuscript accepted on November 7, 2021

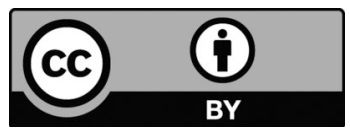

Motriz. The Journal of Physical Education. UNESP. Rio Claro, SP, Brazil - eISSN: 1980-6574 - under a license Creative Commons - Version 4.0 